\title{
Financial Performance Analysis of Go-Public Company on Sector Agriculture in Indonesia
}

\author{
Syam Widia ${ }^{1}$, Anindya Ardiansari ${ }^{2}$, Desti Ranihusna ${ }^{3}$, Fanny Diah Permatasari ${ }^{4}$ \\ \{widias@mail.unnes.ac.id ${ }^{1}$ \} \\ Universitas Negeri Semarang, Indonesia ${ }^{1,2,3,4}$
}

\begin{abstract}
Agriculture consistently becomes an unfavorited sector in Indonesian publictraded. Investor's interest in this sector is still very low, only $8,1 \%$ out of total investment in 2018. The fact has proven that the agriculture sector plays an important role in the Indonesian economy for labor forces. The Indonesian government has been trying many ways to improve the investment inflow to this sector. The financial performance of the agriculture sector is finally would be the spotlight. This paper aims to measure and analyst the financial performance of public-traded the agriculture sector in Indonesia for soon to be a reference to investors. The authors of this research using all listed company of the agriculture sector which published before 2018. The authors measure how is the financial performance of the agriculture sector from 2014-2018 using profitability ratio (ROA), liquidity ratio (CR), solvency ratio (DER), and firm value (PBV). All the ratios will be checked the effect on their each-price stocks. The agriculture sector has a good performance in overall, but we have to put much attentions in profitability ratio (ROA). The strong financial performance in the agriculture sectors in Indonesia are BISI, LSIP, and SSMS. From the t-test examination shows that ROA have positively significant effect to stock price. CR and DER are negatively affect significant to stock price. Meanwhile PBV is negatively insignificant effect to stock price.
\end{abstract}

Keywords: Financial Performance, Financial ratios, the agriculture sector, Public Trade

\section{Introduction}

The public-list companies of the agriculture sector in Indonesia seems not attractive enough for investors. The Investment Coordinating Board (BKPM in Indonesia-red) in January 2018 has released domestic investment data (PMDN in Indonesia-red) and foreign investment data (PMA in Indonesia-red) for the 4th Quarter 2017 whose figured out around IDR 692,8 trillion. That figure has risen to $13,05 \%$ from the investment of PMDN and PMA in 2016 for the same period. However, the agricultural sector only reached $8,1 \%$ out of the total investment or around IDR 14,6 trillion.

In term of the agriculture sector's contribution to Gross Domestic Product (GDP) has shown a downward trend for thee three decades [1]. In 1990, the contribution of the agricultural sector to GDP was $22 \%$. The GDP of Indonesia have been increased significantly over the next two decades. In 2000 the GDP of Indonesia was US\$ 165,02 billion only. The number has jumped over four times to US\$ 755,09billion in 2010. Unfortunately, the contribution of the agricultural sector has been declined by $6 \%$ and $4 \%$ respectively from the previous two decades. In the end, in 2018 the agricultural sector continues a negative trend down to $13 \%$ of GDP. 
Looking from the labor absorption side, the role of the agriculture sector in Indonesia has a quite big number and so strategic actually. During the period 1996-2002, for every 10 Indonesian workers, 4 to5 among them worked in that business field on average [2]. On a regional scale, for example in Banten, the agricultural sector contributed the largest contribution to the labor force compared to other sectors [3]. The large contribution of employment in the agricultural sector will also effect on improving a country's economic development [4][5].

Due to the important role of the agricultural sector, the government through the Ministry of Agriculture Indonesia keeps trying to increase investment flow into the public-traded agricultural sector. This is also in line with the statement of the Chairperson of the Indonesian Young Entrepreneurs (HIPMI-red) that the entry process for investors of the agricultural sector, should not get the obstacles or too complicates by the procedural issues [6]. Once again, it is because of the labor enforcement has contributed greatly to the agricultural sector. According to republika.co.id, the Director of Corporate Affair at the Asian Ministry of Agriculture said that the government will try to attract investors through the one single submission (OSS) and tax holiday programs. The Indonesian government hopes those programs will increase the investor interest and un-strict procedure, so it will ultimately be beneficial to this sector and in line with an increasing job vacancy for Indonesian.

In 2018 the Ministry of Agriculture Indonesia make another effort to support and encourage investment flow. Through the Head of Agricultural Quarantine Agency reported by trubus.id, the government will strive to increase investment to encourage exports in the following sub-sectors: farms, horticulture, plantations, infrastructure, and crops. Four breakthroughs will be made are priority services, in-line inspection, quarantine protocol, and ecertificate.

\section{Purpose}

The authors want to support the government's effort to increase the investment flow in the agriculture sector. This research interest is measuring the financial performance of the publictraded of the agriculture sectors. The authors hope this research soon be supporting data for the prospective investors to glance at the agriculture sectors once again. Most investors use financial statements as a consideration before they decide where should invest their money. However, financial statements that used as an indicator in assessing the success or failure of an organization (in all sectors) do not seem to provide precise information about company performance in a certain period or series [7]. The financial ratio, financial performance, and organizational sustainability have been widely discussed as agricultural financial literature [7]. The historical financial performance of public-listed companies in America examines the median of profitability, liquidity, operating effectiveness, and market ratio [8]. Another finding of the agriculture sector's research was the relationships of liquidity ad solvency to cost efficiency from Kansas Farm [9].

\section{Overview of Public-Traded Agricultural Sector in Indonesia}

Public-trade companies are the companies that some of their stocks owned by the public. The stocks are traded in the stock exchange and its freely owned by the public. The publictrades companies have more advantages in term of financing since can issues more stocks, have 
more access to finance, but also must comply with the rules of its stock exchange and taxation [8].

Indonesia is well known as an agrarian country. Unfortunately, the agriculture sector just starts to listed in the Indonesian Stock Exchange (IDX) in 1990. The first listed or Initial Public Offering (IPO) was PT Bakrie Sumatra Plantation. Two years later, in 1992, followed by PT Smart, it is also the plantation company. These two have the same background, which is palm plantation. Over three past decades, there are 22 companies listed on IDX now. Comparing to all sectors in IDX, this is the lowest number of stock sector categories [10].

There are five main sub-sectors qualification from the agricultural sector in IDX. The five sub-sectors show in figure 1.

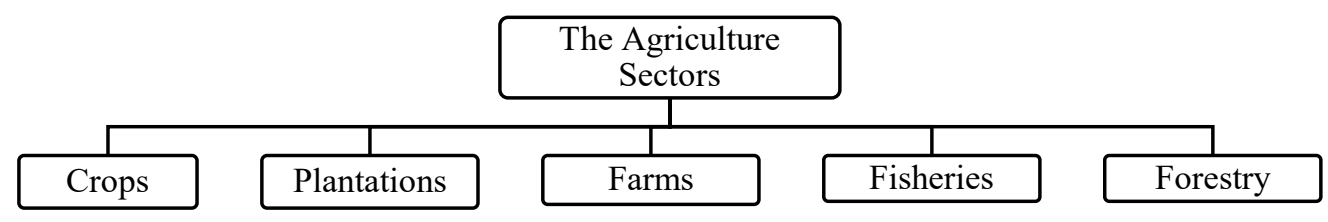

Fig. 1. Agriculture's Sub-Sectors in Indonesia Sources: the authors (2020).

Plantation's sub-sector is the largest sub-sectors with nineteen (19) companies there. Uniquely, none of the listed emiten from forestry sub-sectors even Indonesia have the large and wide of forestry land and some of them managed by a private company. The rest of another subsectors filled by at least one company each.

\section{Financial Literature}

There are many studies in various countries conducted on the measurement of the agriculture public sector performances, both for financial performances and business strategy. Paulson, Katchova and Enlow [8] found that the agribusiness sector outperformed the median sample of all companies listed in America in terms of profitability; liquidity; and market ratios, but slightly lower in liquidity and debt ratio. Another researcher, deepening the relationship between the agricultural sector with macroeconomic factors with farms companies' financial health. The result found that variables at the sector level and farms had the most significant influence on the profitability of default (PD) migration of the credit farms in Mid-America [11].

In Indonesia, Kurniadi, Achsani and Sasongko [12] have examined the financial performance of the public-traded company of the agriculture sector using Economics Value Added (EVA), Market Value Added (MVA), and also Q-tobin. The results showed that most companies obtained negative EVA. While the measurement result using MVA showed most companies have positive results. Using Q-Tobin formula, the result also showed that most companies have value $\mathrm{q}<1$.

The other researchers measure the risk mitigation of investing in agribusiness shares by creating a portfolio analysis. The result pointed out two best stock combinations in the publictraded agricultural sector companies. First is $30 \%$ of LSIP shares and $70 \%$ of AALI shares. The second one is $20 \%$ of LSIP shares and $80 \%$ AALI shares. Both of these stocks' combinations are in the optimal portfolio [13]. 
Syamni [14] examined the effect of corporate social responsibility (CSR) on profitability in public-listed the agricultural sectors on the Indonesian Stock Exchange (IDX). The results showed that companies in which doing CSR get a better profitability index using return on equity (ROE) valuation method in plantation companies. Since the public-trade of the agriculture sector in Indonesia dominated by plantation companies, so this result indicates that CSR has a positive signal for investors when deciding to invest in the capital market.

The stock price movement of the agricultural sector because of macroeconomics influences in Indonesia has been researched too. The results showed that in the long term, the movement the agricultural sector's stock price index was not influenced by the BI rate variable, but negatively influenced by the rupiah (IDR) exchange rate variables against the US\$ dollar, the money supply, and the palm oil's price. Whereas in the short term, it is only palm oil's price that will affect the stock price of the agricultural sector's movement index [15].

The authors focus on measuring the financial performance of public-traded the agriculture sector companies. As stated earlier, the agriculture sector has not received much attention or interest from the investors. The researchers will also measure how is the financial performance affecting the stock price in the agricultural sectors. There are few numbers of literacy in this sector, although it substantially demonstrates their economic strength as a market sector [8]. The results of this research are expected to be used as financial literacy for potential investors.

\section{Data}

The researchers use the financial performance data from the public-trade agriculture sector which lists on IDX. The agriculture sector is classified into five sub-sectors which consist of 22 companies. This research only used sixteen companies because the rest companies just listed on IDX in 2018 and thereafter. Therefore, time-series data for previous years are unavailable. Table 1 shows the following emiten list that will use in this study.

Table 1. The Public-traded of Agriculture Sector Companies

\begin{tabular}{|c|c|c|}
\hline No & Emiten's Code & Listed Companies \\
\hline 1 & AALI & Astra Agro Lestari, Tbk \\
\hline 2 & ANJT & Austindo Nusantara Jaya, Tbk \\
\hline 3 & BISI & BISI Internasional, Tbk \\
\hline 4 & BWPT & Eagle High Plantations, Tbk \\
\hline 5 & DSFI & Dharma Samudera Fishing Indust, Tbk \\
\hline 6 & DSNG & Golden Plantation, Tbk \\
\hline 7 & GOLL & Gozco Plantation, Tbk \\
\hline 8 & GZCO & Jaya Agra Wattie, Tbk \\
\hline 9 & JAWA & PP London Sumatera Indonesia, Tbk \\
\hline 10 & LSIP & Providi Agro Gemilang Plantations, Tbk \\
\hline 11 & MAGP & Sampoerna Agro, Tbk \\
\hline 12 & PALM & Salim Ivomas Pratama, Tbk \\
\hline 13 & SGRO & Smart, Tbk \\
\hline 14 & SIMP & Sawit Sumbermas Sarana, Tbk \\
\hline 15 & SMAR & SSMS \\
\hline 16 & & \\
\hline
\end{tabular}


This research uses time-series data. It is financial performance data from 2014 to 2018 . IDX has not released the latest data period, 2019, that is why the researchers use the data until 2018 only. The authors admit there are limitations from this dataset for historical analysis. Data for some companies from IDX was also unavailable and incomplete in some cases. So, the authors decided to calculate manually.

\section{Financial Performance Measurement}

When evaluating financial performance, indicators of valuation can refer to an absolute performance appraisal based on the figures in the financial statements (balance sheet and income statements) and financial ratios [8]. Financial performances in this research were measured by using financial ratios. Financial ratios as variables in performance valuations are commonly used in various studies [16][17][18]. In this study, the researchers use liquidity ratio, profitability ratio, solvency ratio, and firm value ratio to measure the financial performance of the agriculture sector.

Liquidity ratio is the ability from the company to fulfill short-term obligations. High level of liquidity ratio shows that the ability of companies to pay off their short-term debt is also higher [9][19]. The liquidity ratio in this research uses the current ratio (CR). CR measures the short-term financial strength of the company (current assets). Current assets include cash, account receivables, inventories, and short-term bonds [19]. The formula of CR follows:

$$
\text { Current Ratio }=\frac{\text { Current Assets }}{\text { Current Liabilities }}
$$

The second ratio is the profitability ratio. The profitability ratio shows the company's fundamental performance in terms of efficiency and effectiveness to gain profits [19]. In this research the authors use return on assets (ROA) to examine profitability ratio. ROA is considered to show the efficiency of the firm performance in managing assets for gaining profit $[20][21][22][23]$. The ROA formula as follows:

$$
\text { Return on Assets }=\frac{\text { Net Income }}{\text { Total Assets }}
$$

Another ratio is to examine the ability of the company's solvency using leverage ratio. The leverage ratio or also known as solvency ratio examines a company's leverage capability related to mix debt and equity, in other words, it is the company's ability to fills its long-terms and short-terms obligations [19]. Larger the amount of corporate debt will be greater the financial risk of bankruptcy too [8]. In Indonesia, practically, many companies bankrupt caused by the funding structure that does not provide the leverage balance because the understanding of capital structure is more partially and not optimal [19]. In this research, the indicator of the leverage ratio is Debt to Equity Ratio (DER). DER shows the capital structure information that affects the firm's value as DER will examine the effectiveness of total debt to the capital of the company itself. DER formula as follows:

$$
\text { Debt to Equity Ratio }=\frac{\text { Total Liabilities }}{\text { Total Equity }}
$$


The last ratio used in this study is the firm value's ratio. Empirical facts show that not all financial performance variables have a significant effect on firm value [19]. The firm's value ratio for this research uses Price to Book Value (PBV). PBV is measuring the price level of the company's stock market with the book value of the stock itself. PBV can explain the relationship between various interested parties regarding the share price of a particular company. PBV can be calculated using this following formula:

$$
\text { Price to Book Value }=\frac{\text { Market Price }}{\text { Book Value per Share }}
$$

\section{Results and Findings}

The researchers use financial ratios to measure the financial performance of the agriculture sector public-traded company in Indonesia. We use data from 2014 to 2018 . Financial ratios we used such as current ratio, ROA, DER, and PBV have shown in Figure 2.
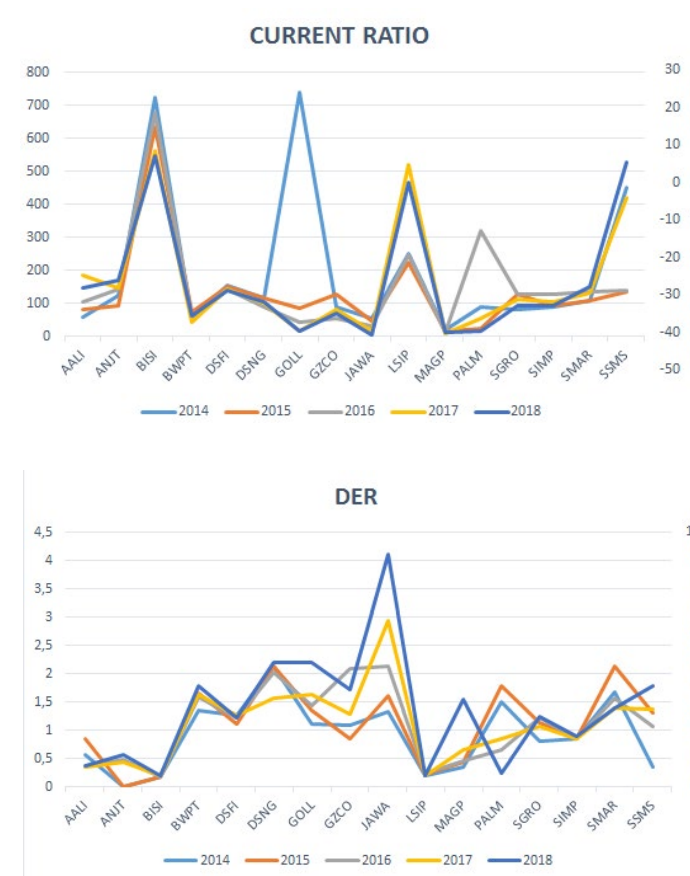

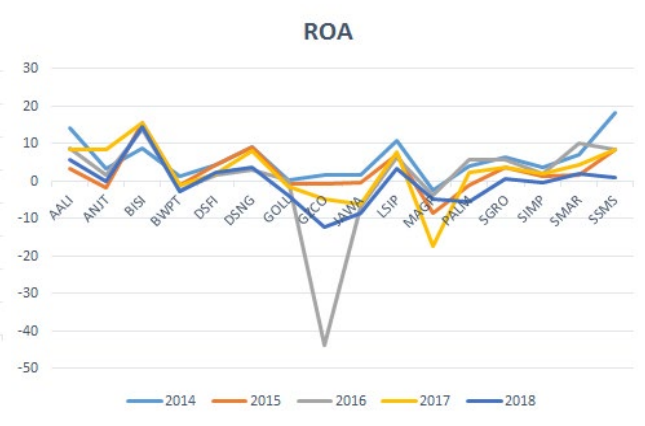

PBV

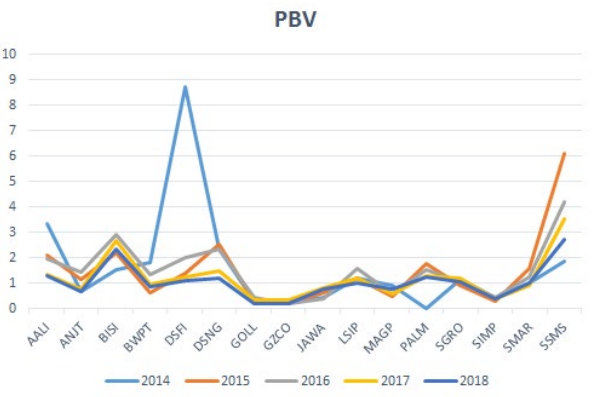

Fig. 2. Financial Ratio of Public-Traded the Agriculture Sector. Source: The Authors.

Figure 2 shows that all public-traded companies in the sector of agriculture have $C R>0$. It means that all companies have the ability to pay off their short-term debts. There are three companies consistently dominant among others emitens with reaching more than $400 \%$. They are BISI, LSIP, and SSMS. Among these three companies, LSIP and SSMS has been an increase significantly more than 3 and 2-fold respectively. In addition, there are 2 other companies that 
are interesting in the CR valuation, namely GOLL in 2014 and PALM in 2016. There jumped in that year.

ROA results show that the agriculture sector has not been able to say much to attract the investors. The ability of their asset management to get more profits has not been optimally. From figure 2, the ROA valuations is less than $20 \%$. Even in $2018,43,75 \%$ of whole go-public companies in the agriculture's sector shown negative ROA index. In 2016, GZCO plunged freely to $-43,64 \%$. Although the following year they as extraordinary can cut the minus to $4,79 \%$. Among the data series, only BISI has consistently produced ROA of more than $13 \%$ since $2015-2018$.

Contrary to profitability ratio, all companies in the agriculture sector have the ability in managing their leverages quite effective. The company that shown the best DER valuation is JAVA. From 2014 to 2018 the increase of DER index was 24,5\% per year. Two companies with lowest effectiveness in managing their leverage are BISI and LSIP with DER of $0.2 \%$.

The last financial ratio is to measure the firm value based on stock market price to price to book-value. Overall, the value of the companies in the sector of agriculture is similar vibe. Figure 2 shows the best result from PBV valuation for the 2014-2018 period is shown by SSMS. However, if considered deeper, most companies in the agriculture sector have negative trend in firm value every year. DSFI had a great initial reputation in 2014 , but freely felt down in following year until 2018. In the end, as average of firm value from this sector was $1.39 \%$, and the researcher know it is not good enough.

The researchers are aware of the presence of contain outliers in calculating means in the financial ratio. It is because of the financial ratio typically contains outlier. We use the median does not suffer from this problem. The median of financial performance of the agriculture sector is shown in the table 2 .

Table 2. Median Financial Performance of the Agriculture Sector

\begin{tabular}{|c|c|c|c|c|c|}
\hline Financial Ratios & 2014 & 2015 & 2016 & 2017 & 2018 \\
\hline CR & 98,07 & 100,745 & 126,17 & 106,7 & 97,5 \\
\hline ROA & 4,185 & 1,38 & 2,475 & 3,025 & 0,315 \\
\hline DER & 1,08 & 1,13 & 1,14 & 1,17 & 1,315 \\
\hline PBV & 1,15 & 1,185 & 1,405 & 1,07 & 1,02 \\
\hline
\end{tabular}

Source: The Authors

The results from table 2 show that in general the median financial performance in the agriculture sector has shown good result. Financial performance in all variables look stagnant, not too fluctuating. However, if you look at ROA variable, it must be on more attention. From 2014 to 2018 the median financial performance declined to 3,87 points. The rest variable ratios did not change too much in the 4 years of research period.

The researchers add one more analysis, it is T-Test analysis. We analysis the relationship of four financial ratios to stock prices of the companies in the agriculture's sector. Stock price is also be indicators that be consideration for shareholders or investor before put their investment. The T-test analysis show in Table 3. T-Test find that all variables data are valid, reliable, and not multicol. The authors find that all variables data are valid, reliable, and not multicol. The t-test value shows that only ROA have positively significant effect to stock price. $\mathrm{CR}$ and DER are negatively affect significant to stock price. Meanwhile PBV is negatively insignificant effect to stock price. 
Table 3. T-Test Table Financial Ratios to Stock Prices

\begin{tabular}{|c|c|c|c|c|c|}
\hline $\begin{array}{c}\text { Financial } \\
\text { Ratios }\end{array}$ & AVE & $\begin{array}{c}\text { Cronbach } \\
\text { alpha }\end{array}$ & Inner VIF & $\begin{array}{c}\text { Original } \\
\text { Sample }\end{array}$ & P Values \\
\hline ROA & 1,000 & 1,000 & 1,000 & 0,246 & 0,010 \\
\hline CR & 1,000 & 1,000 & 1,000 & $-0,226$ & 0,014 \\
\hline DER & 1,000 & 1,000 & 1,000 & $-0,176$ & 0,025 \\
\hline PBV & 1,000 & 1,000 & 1,000 & 0,044 & 0,697 \\
\hline
\end{tabular}

Source: The Authors.

\section{Conclusion}

The authors presented the financial analysis for public-listed company in the agriculture sector in Indonesia. In conducting our analysis, we use the financial ratios as the basic knowledge for analyzing financial performance. The researchers use all indicator ratios to examines the financial ratios, such as liquidity ratio, profitability ratio, debt ratio, and firm value ratio. In this research, we also added the several analysis methods like t-test analysis and statistical test. We admit that in this research we use the financial literacy and prior research as literacy. We try to provide better analysis of financial performance of the agriculture sector in Indonesia. From our finding, the agriculture sector has a good performance in overall, but we have to put much attentions in profitability ratio (ROA). The strong financial performance in the agriculture sectors are BISI, LSIP, and SSMS. In general, median performance of this sector also good and effective. From the t-test examination shows that ROA have positively significant effect to stock price. It is unique since ROA in financial ratio not really present good valuation in this sector. Next, CR and DER are negatively affect significant to stock price. Meanwhile $\mathrm{PBV}$ is negatively insignificant effect to stock price.

The question that arises for the next research is if the profitability ratios used other than ROA will be like. Suppose we will examine using Return on Equity (ROE) for profitability ratio or Earning Per Shares (EPS) for firm value ratio. What the result will be. For the next research we hope our research can contribute as a literature. If we will continue our research, we will compare the financial performance of the agriculture sectors to all of sectors of public-trade firms in IDX. So that will get deeper analysis to the agriculture sector.

\section{References}

[1] World Bank, "Data Bank: Country Profile," 2019.

[2] I. Setiawan, "Peran sektor pertanian dalam penyerapan tenaga kerja di Indonesia," J. Geogr. Gea, vol. 6 , no. $1,2006$.

[3] M. F. Alexandi and O. Marshafeni, "Penyerapan Tenaga Kerja Pada Sektor Pertanian Dan Sektor Jasa Pascakebijakan Upah Minimum Di Provinsi Banten (Periode Tahun 2001-2011)," J. Manaj. Agribisnis, vol. 10, no. 2, pp. 71-80, 2014.

[4] H. E. Chebbi, "Agriculture and economic growth in Tunisia," China Agric. Econ. Rev., 2010.

[5] A. S. Ibidunni, D. E. Ufua, U. E. Okorie, and B. E. Kehinde, "Labour productivity in agricultural sector of Sub-Sahara Africa (2010-2017)," African J. Econ. Manag. Stud., 2019.

[6] D. Finance, "Ketum HIPMI Bicara Iklim Investasi Pertanian RI," 2019. [Online]. Available: https://finance.detik.com/berita-ekonomi-bisnis/d-4701048/ketum-hipmi-bicara-iklim-investasipertanian-di-ri.

[7] N. Purves, S. J. Niblock, and K. Sloan, "On the relationship between financial and non-financial factors," Agric. Financ. Rev., 2015. 
[8] N. Paulson, A. L. Katchova, and S. J. Enlow, "Financial performance of publicly-traded agribusinesses," Agric. Financ. Rev., 2013.

[9] L. A. Russell, M. R. Langemeier, and B. C. Briggeman, "The impact of liquidity and solvency on cost efficiency," Agric. Financ. Rev., 2013.

[10] Badan Koordinasi Penanaman Modal, "Sektor Pertanian Indonesia," 2018. [Online]. Available: https://www.investindonesia.go.id/id/artikel-investasi/detail/sektor-pertanian-di-indonesia.

[11] A. M. Johnson, M. D. Boehlje, and M. A. Gunderson, "Agricultural credit risk and the macroeconomy," Agric. Financ. Rev., 2017.

[12] A. Kurniadi, N. A. Achsani, and H. Sasongko, "Kinerja keuangan berbasis penciptaan nilai, faktor makroekonomi dan pengaruhnya terhadap return saham sektor pertanian," J. Akunt. dan Keuang., vol. 15 , no. 2, pp. 63-74, 2013.

[13] E. Asliana, "Analisis Investasi Saham Perusahaan Go Public Sektor Pertanian di Bursa Efek Jakarta," EKUITAS (Jurnal Ekon. dan Keuangan), vol. 11, no. 3, pp. 391-410, 2018.

[14] G. Syamni, "CSR and Profitability in IDX Agricultural Subsectors," in Proceedings of MICoMS 2017, Emerald Publishing Limited, 2018.

[15] P. Andiantyo, P. Sihombing, and S. Y. Kusumastuti, "Pergerakan Indeks Harga Saham Sektor Pertanian di Bursa Efek Indonesia," in Prosiding Seminar Nasional Cendekiawan, 2018, pp. $1137-1148$.

[16] N. Alverniatha and S. Dossugi, "Analisis Perbandingan Economic Value Added (EVA) dan Financial Value Added (FVA) Sebagai Alat Ukur Penilaian Kinerja Keuangan pada Industri Perkebunan di Bursa Efek Indonesia," J. Appl. Financ. Account., vol. 3, no. 1, pp. 75-92, 2010.

[17] N. Bharti, "Evolution of agriculture finance in India: a historical perspective," Agric. Financ. Rev., 2018.

[18] G. Feder, R. Birner, and J. R. Anderson, "The private sector's role in agricultural extension systems: potential and limitations," J. Agribus. Dev. Emerg. Econ., 2011.

[19] Harmono, "Berbasis Balanced Scorecard Pendekatan Teori, Kasus, dan Riset Bisnis, Jakarta: PT," Bumi Aksara, 2017.

[20] C. L. Escalante, C. G. Turvey, and P. J. Barry, "Farm business decisions and the sustainable growth challenge paradigm," Agric. Financ. Rev., 2009.

[21] S. N. Tanzil and J. J. Juniarti, "Pengaruh Struktur Kepemilikan Keluarga Terhadap Kinerja Perusahaan Pada Sektor Perdagangan, Jasa, dan Investasi," Bus. Account. Rev., vol. 5, no. 2, pp. 241-252, 2017.

[22] X. Shen and V. Hartarska, "Derivatives as risk management and performance of agricultural banks," Agric. Financ. Rev., 2013.

[23] K. P. Pokharel, M. Regmi, A. M. Featherstone, and D. W. Archer, "Examining the financial performance of agricultural cooperatives in the USA," Agric. Financ. Rev., 2019. 